\title{
Unsystematic Systems
}

\section{Vered Amit and Noel Dyck}

This special issue reports the findings of a research team of senior anthropologists, Vered Amit and Noel Dyck, and three graduate research assistants, Heather Barnick, Meghan Gilgunn, and Kathleen Rice, collaboratively investigating the workings of policies on the movements of student and youth from Canada. Specifically our focus is on three different types of movement: international student exchanges, working holidays, and international athletic scholarships. While our focus is on movement out of Canada, these are, to say the least, forms of mobility that have their analogues, sometimes on a much larger scale, in many other affluent industrial countries.

What is especially significant about these forms of transnational movements, both within and without Canada, is that they are governed by policies and regulations explicitly oriented towards students and/or youths as clients. It is not surprising therefore to find that the institutional rationales framing these forms of travel tend to be imbued with notions of social reproduction. Travel has frequently been identified with or promoted as a vehicle for selftransformation (Graburn, 1983; Bruner, 1991). But in the circumstances with which we are concerned in this journal issue, the cultivation of the youthful traveller tends to be treated by institutional patrons more specifically as forms of socialization. As such the valorization of these forms of movement often elicits many of the themes of morality, necessity, futurity, and collective good that are also attributed to other forms of socialisation (James, Jenks, and Prout, 1998; Olwig and Gullov, 2003).
But the contemporary development and promotion of student mobility has also involved more or less overtly instrumental and pecuniary purposes. Put crassly the transnational movement of students is 'big business'. Students pay tuition fees, buy services, work as transient labourers or as star athletes and as such their movement across state borders can generate fairly substantial revenues. As Vered Amit and Noel Dyck discuss in their respective papers in this issue, it is the linkage between, on the one hand, the instrumental interests and, on the other, the moral discourses of socialisation that can be attached to student mobility (and indeed the educational system generally) which provide it with some of its most emotively persuasive but also its most controversial accents. It is this linkage, for example, that is most likely to elicit suggestions that institutional patrons of student mobility, whether from government, education, or business, are using altruistic aspirations as a convenient cover for the pursuit of calculated economic interests. But in the forms of movement upon which our research has focused, the statuses of students both as revenue generating clients as well as subjects of moral discourses of social reproduction are murky, or put another way, these forms of student mobility trouble both institutional claims of socialization as well as of economic rationality.

\section{Troubling Socialisation Claims}

Officials promoting opportunities for students to have extended stays abroad, whether on 
study or work programmes, often cite the importance of 'international experience' for cultivating the perspectives and skills needed to operate effectively in an interconnected world and globalised economy. Such claims continue to be made, even when there is little direct evidence to substantiate this formative effect on students and youths who take part in such forms of travel. As Vered Amit notes in her contribution, students don't always go to the destinations nor do they spend as much time there as the officials concerned with inculcating a more internationalist horizon would necessarily desire. And young participants in these kinds of movements may have very different motivations for their participation than their institutional patrons might desire or claim. For the young Canadian students that Heather Barnick encountered in Australia, a primary motivation for participating in an exchange was the chance that it afforded for travel before one became too encumbered with adult commitments, and it was too 'late', a 'time out' that could be incorporated into their studies. Kathleen Rice outlines the encapsulation of Canadians spending a working holiday in Edinburgh. Many of these young sojourners were working in the hospitality industry, which they were also patronizing as clients, often in the very youth hostels where they were either still residing or had resided when they first arrived. Working holiday-makers tended to seek out and socialise primarily with other youthful travellers even when their work afforded them contact with local residents. In short, the 'international experiences' enabled by their mobility were circumscribed in scope and effect.

Winning a 'full ride' athletic scholarship to attend an American post-secondary institution is an aspiration that has become integrated into an increasing range of children's community sport in Canada. The prestige attributed to such a scholarship is supposed to derive from the support it provides for talented athletes who wish to pursue a good education at well-regarded American universities. But, as both Noel Dyck and Megan Gilgunn describe in their respective contributions, the level of athletic commitment required of students who achieve this goal often limits either the attention they can devote to their academic studies and/or the type of studies of which they may be capable or which they are encouraged to undertake. In other words, taking up an athletic scholarship in an American post-secondary institution may come at the expense of more explicitly academic concerns.

\section{Troubling Internationalisation and Economic Interest}

Our initial interest in these particular forms of movement was, however, especially provoked by the increasing pervasiveness of an institutional discourse of internationalisation in the post-secondary sector in Canada and its counterparts in many similarly affluent, industrialised countries. The formalisation of internationalisation as an umbrella for a variety of academic activities, some new and some longstanding, appears to have been associated with the contentious rise of a form of academic entrepreneurialism. This orientation has made itself felt especially in transnational competition between institutions for a share of the lucrative international full degree student market. In other words, the formalisation and promotion of internationalisation has been associated with a growing willingness to view education as a form of potentially profitable international trade. But here again, the kinds of movements on which we have focused complicate the parameters of this discourse.

While student exchanges are often explicitly promoted by universities as a critical part of their strategies for internationalisation, this is a form of mobility that does not generate extra revenue for the host institution since students continue to pay regular fees to their home rather than host institution. Indeed post-secondary institutions often have to expend extra resources 
to administer these programmes, to accommodate incoming students, or sometimes to provide financial incentives to encourage students to take up these opportunities. Meanwhile, working holiday-maker arrangements sit on the periphery of educational training, deliberately blurring the distinctions between education, tourism, and migration. While bilateral working holiday-maker agreements are entered into and regulated by government departments and are therefore not directly associated with academic institutions as patrons, they are frequently undertaken in and around education schedules, either as a break (as in the British gap year) between one level of education and another, as an interval between successive years in a degree programme, or as an interlude between completion of an academic degree and long term career commitments. Indeed some countries have explicitly linked the eligibility of visitors to participate in their working holiday-maker programme to recent or ongoing student status and others have used age limits to ensure that only youths or young adults be enlisted. In Canada, prospective student travellers often use the services of student travel agencies to make visa and travel arrangements for their working holidays. Finally while working holiday-maker provisions allow young people to work for limited periods in a country they are visiting, they are usually regulated as a form of tourism.

Of the three programmes on which we have focused, it is the trans-border movement of Canadians to take up their post-secondary studies in American institutions as elite student athletes that most closely approximates to the focus on competition for international students associated with internationalisation. Because of the three forms of movement with which we have been concerned, only this one involves students leaving their countries to complete a full degree at a foreign university. Yet ironically it is this programme that is least likely to be framed by officials in terms of internationalisation. Instead as Noel Dyck notes,
American athletic department officials tended to minimise the foreign nationality of varsity athletes, emphasizing instead that Canadian students 'appear to fit as easily into their programs as do their American teammates'.

If internationalisation has often been primarily construed as part of a transnational competition between universities for lucrative international students, the nature of the revenues generated when Canadian athletes are recruited is especially ambiguous. By definition, the students we included in our study had all received some sort of scholarship to attend an American university. But as Meghan Gilgunn explains, this was far from the 'free' education that many Canadians associate with an athletic scholarship. Many student athletes receive only partial scholarships and even the fortunate few who are on 'full rides' have many additional expenses not covered by their scholarships. As a result, Canadian varsity athletes on scholarship at American institutions often incur more expenses than if they had attended a Canadian university without any financial assistance. On the other hand, the complicated and much debated question of the balance sheet between the cost of and revenues generated by athletic programmes at American universities suggests that the participation even of Canadian athletes on scholarship may still be viewed in some equations as 'profitable' by the officials recruiting them.

In short, while there has been an increasing tendency to regard the cross border movement of students as a form of international trade, the three types of student mobility on which we have focused suggest that the scope and accounting of the financial balance sheet that is generated by student mobility is far from crystal clear.

\section{Unsystematic Systems}

In noting the fragmented nature of policy, Cris Shore and Susan Wright have argued that a 
principal objective of 'organizing is to make these fragmented activities appear coherent, so it can be claimed that an intention has been realized and a successful result achieved' (1997: 5). Such an observation certainly could be applied to the range of policies associated with student mobility. But beyond the deliberate, usually discursive efforts to shape an appearance of coherence, what also protects policies from collapsing under the weight of their inconsistencies and fragmentation is the fact that participants often do not need to know more than a little piece of the procedures or workings of a particular policy in order to take part in some aspect of its application. That is, in some respects it is the very extent and effectiveness of the fragmentation of policy that enables people to carry on without having to confront the contradictions or incoherence of the systems or procedures in which they are participating. As the articles in this special issue illustrate, sometimes this partial scrutiny is incidental and sometimes it is deliberate.

The officials developing and managing university exchanges or working holidays have limited means of tracking the students participating in these activities either when they are abroad or on their return. As a result, they do not have much substantive knowledge about the nature of these experiences of mobility or its longer-term effect on participating students. But this does not really hamper the capacity of officials to draw up new bilateral agreements between universities, governments, or voluntary associations. It does not impede the capacity of organisers to recruit students as participants or of lobbyists seeking to promote internationalisation. Nor do officials and organisers working in different aspects of these kinds of programmes necessarily have much interaction with or knowledge of each other's sphere of operation. At the same time students really do not need to know very much about - and, as Heather Barnick and Kathleen Rice illustrate, evince little interest in - official representations of these programmes or the modalities through which agreements on exchanges, visas, scholarships are reached. They need to know only just as much as will allow them to participate in programmes of mobility.

Much of this partiality is a feature of the unsystematic nature of the systems through which students move between universities, job markets, countries. But this partial perspective can also be a result of determined efforts not to know. As Noel Dyck explains in his contribution to this special issue, there appears to be a determined effort by Canadian parents, coaches, and talented athletes to evade the controversies and debates in the United States, which revolve around varsity sports programmes in post secondary educational institutions. The silence in Canada regarding this debate is all the more striking given the otherwise high exposure of Canadians to and interest in American media, politics, economy, and so on. But this evasion and, as Meghan Gilgun illustrates, the insistence of many Canadian students athletes that it is 'worth it', is what allows particular interpretations of an athletic scholarship in an important segment of Canadian amateur and community sports to be perpetuated without contradiction.

The disjunctions through which policies are generated, applied, and experienced pose special challenges for constructing a field of investigation. As a team we were able to interview numerous students in Canada before or after they returned from a sojourn abroad; to observe and engage with students on exchange in Australia, on a working holiday in the UK, or supported by an athletic scholarship in the United States. We were able to interview officials from universities, student associations, government departments, non-governmental associations in Canada, the United States, Australia, and to a much lesser extent in the United Kingdom. Given more time we undoubtedly would have been able to make contact with a wider range of actors or situations. But these are not matters of simple addition in which one 
can investigate pieces cumulatively that join up to complete the puzzle. The various agents we encountered and the vehicles and circumstances of movement often made it easier to deconstruct the workings of policies than to connect the dots. In other words, policies are often generated through more or less incidental disjunction. As a result, at every step in our investigation we have become aware ever more palpably of the inescapable absences and partialities that attend an investigation of the development and application of policies.

\section{Acknowledgements}

The project on which this special issue of $A n$ thropology in Action reports was made possible by a standard research grant from the Social Sciences and Humanities Research Council of Canada; entitled "Coming of Age in an Era of Globalization: Achieving Cultural Distinction through Student Travel Abroad", awarded to Vered Amit and Noel Dyck as co-applicants. We would like to thank Heather Barnick, Meghan Gilgunn, and Kathleen Rice for their contributions to this project.

\section{References}

Bruner, Edward (1991), 'Transformation of Self in Tourism', Annals of Tourism Research, 18: 238-250. Graburn, Nelson (1983), 'The Anthropology of Tourism', Annals of Tourism Research, 10, no. 1: 174-187.

James, Allison, Chris Jenks, and Alan Prout (1998), Theorizing Childhood (Oxford: Polity Press).

Olwig, Karen Fog and Eva Gulløv (eds.) (2003), Children's Places: Cross-Cultural Perspectives (London and New York: Routledge).

Shore, Cris and Susan Wright (1997), 'Policy: A New Field of Anthropology', in Anthropology of Policy: Critical Perspectives on Governance and Power, (ed.) Cris Shore and Susan Wright (London and New York: Routledge), 3-39. 